\title{
Perencanaan Ulang Tube Boiler Type AL-LSB-6000 pada Pusat Pengembangan Sumber Daya Manusia Minyak dan Gas Cepu
}

\author{
Ali Fajar Nugroho ${ }^{1, a)}$, Nurmuhamad Iskandar ${ }^{2, b)}$, Ochtafian Wahyu Irawan ${ }^{3, c)}$ \\ 1,2,3 Program Studi Teknik Mesin ITI, \\ Jl. Raya Puspiptek Serpong, Tangerang Selatan-Banten, Indonesia, 15320 \\ a) alinugroho89@gmail.com ${ }^{\text {b) }}$ muhammadiskandar861@gmail.com, ${ }^{\text {c) }}$ z.ochtafian@gmail.com
}

\begin{abstract}
Abstrak
Pusat Pengembangan Sumber Daya Manusia Minyak dan Gas Cepu memiliki boiler tipe $A L-L S B-6000$, dimana didapatkan suatu kasus yaitu besarnya tegangan yang terjadi pada tube boiler dikarenakan material yang dipakai mempunyai spesifikasi nilai tegangan yang tinggi. Metode yang digunakan pada perencanaan ini diawali dengan observasi pada PPSDM Migas Cepu, melakukan proses perencanaan perhitungan kekuatan material sebelumnya sesuai ASME. Analisa perencanaan berupa perbandingan perhitungan manual maupun perhitungan simulasi pada software material SA 192 dengan material SA 53. Hasil yang didapat berupa rancangan hitung dan desain tube boiler. Analisis perhitungan pada SA 192 memiliki nilai tegangan 11,67 Mpa, sedangkan pada simulasi software nilai tegangan 11,63 Mpa. SA 53 memiliki nilai tegangan 9,09 Mpa, sedangkan pada simulasi software nilai tegangan 9,14 Mpa. Material SA192 memiliki nilai tegangan lebih besar dibanding SA 53.
\end{abstract}

Kata kunci: tube boiler, waktu pemanasan, numerik, FEA

\begin{abstract}
Cepu Oil and Gas Human Resources Development Center has a boiler type AL-LSB-6000, which has a case of the amount of stress that occurs in tube boilers because the material used has a high stress value specification. The method used in this planning begins with observation on PPSDM Migas Cepu, conducting the planning process of calculating the previous material strength according to ASME. Planning analysis in the form of comparison of manual calculation and simulation calculation in SA 192 material software with SA 53 material. The obtained results are in the form of calculated design and boiler tube design. Calculation analysis in SA 192 yields stress value of $11.67 \mathrm{Mpa}$, while in software simulation yields stress value of $11.63 \mathrm{Mpa}$. SA 53 has stress value of $9.09 \mathrm{Mpa}$, while in software simulation yields stress value of 9.14 Mpa. Material SA192 has a greater stress value than SA 53.
\end{abstract}

Keywords: tube boiler, stress, numeric, FEA

\section{PENDAhuluan}

A. Latar Belakang

Energi memiliki peran yang sangat krusial untuk memenuhi kebutuhan sehari - hari bahkan di dunia industri kebutuhan energi dunia terus mengalami peningkatan. Kebutuhan energi terus mengalami peningkatan seiring dengan meningkatnya kegiatan pembangunan ekonomi suatu negara tidak terkecuali di Indonesia. Menurut proyeksi Badan Energi Dunia (International Energy Agency - IEA), hingga tahun 2030 permintaan energi dunia meningkat sebesar $45 \%$ atau rata-rata mengalami peningkatan sebesar $1,6 \%$ pertahun [1]. Sumber energi yang terkandung di Indonesia diyakini belum mampu dimaksimalkan secara sempurna untuk memenuhi kebutuhan energi nasional, hal ini mengakibatkan masih adanya daerah-daerah di Indonesia yang belum dialiri energi secara total. Pengolahan kekayaan sumber daya energi yang ada di Indonesia dengan baik dan tepat akan menghasilkan energi yang cukup bahkan lebih untuk memenuhi kebutuhan energi nasional. Hal ini memaksa masyarakat untuk bertanggung jawab dalam penggunaan dan pemanfaatan sumber energi secara bijaksana.

Boiler atau ketel uap adalah suatu alat berbentuk bejana tertutup yang digunakan untuk memproduksi steam/uap. Steam diperoleh dengan memanaskan air yang berada di dalam bejana dengan bahan bakar. Boiler mengubah energi-energi kimia menjadi bentuk energi yang lain untuk menghasilkan kerja. Adapun cara melakukan perancangan ulang yaitu dengan mengetahui data-data yang telah didapat pada saat melakukan penelitian di Pusat Pengembangan Sumber Daya Manusia Minyak Gas Cepu, dan mendesign ulang tube boiler type $A L-L S B-6000$ ini dengan menggunakan software FEA, yaitu menggunakan software ANSYS 17.0 yang mensimulasikan tegangan pada tube boiler Berdasarkan analisa pada saat pengambilan data di PPSDM Migas Cepu didapatkan suatu kasus yaitu tingginya nilai dari tegangan pada tube boiler dikarenakan spesifikasi material memiliki nilai tinggi terhadap tegangan, maka 
dari itu penulis bermaksud melakukan perencanaan ulang tube boiler type AL-LSB-6000 pada Pusat Pengembangan Sumber Daya Manusia Minyak Dan Gas Cepu.

\section{B. Rumusan Masalah}

Perumusan masalah pada penelitian ini adalah merancang tube boiler type AL-LSB-6000 dengan mengikuti standar ASME dan sesuai kebutuhan pada Pusat Pengembangan Sumber Daya Manusia Minyak Dan Gas Cepu.

\section{Tujuan Penelitian}

Tujuan penelitian ini adalah merencanakan ulang tube boiler type AL-LSB-6000 sesuai standar ASME menggunakan material lama dengan material baru.

\section{Batasan Masalah}

Pada penelitian ini memiliki batasan masalah yang hanya membahas mengenai beberapa faktor. Berikut batasan masalah pada penelitian ini:

1. Perancangan ulang tube boiler type AL-LSB-6000 dengan menyesuaikan data yang diambil pada PPSDM Migas Cepu.

2. Perencanaan dihitung secara manual dan menggunakan software ANSYS 17.0.

3. Tube boiler yang dirancang adalah tipe fire tube boiler.

\section{LANDASAN TEORI}

\section{A. Pengertian Ketel Uap (Boiler)}

Boiler atau ketel uap adalah suatu alat berbentuk bejana tertutup yang digunakan untuk memproduksi steam/uap. Steam diperoleh dengan memanaskan air yang berada didalam bejana dengan bahan bakar. Boiler mengubah energi-energi kimia menjadi bentuk energi yang lain untuk menghasilkan kerja. Boiler dirancang untuk memindahkan kalor dari suatu sumber pembakaran, yang biasanya berupa pembakaran bahan bakar. Boiler adalah sebuah konteiner dimana diberi air dan dipanaskan, sehingga air mendidih dan menguap terus menerus menjadi uap. Uap (steam) yang dihasilkan dari boiler digunakan untuk berbagai proses dalam aplikasi industri, seperti penggerak, pemanas, dan lainlain. Pengoperasian boiler harus sesuai dengan standar operasi yang telah ditentukan oleh pengguna boiler maupun standar pabrik pembuat boiler itu sendiri [2]. Standar yang dibuat akan menjamin keamanan dalam pengoperasian, sehingga akan meningkatkan efisiensi ketel uap sekaligus menekan biaya operasional

Boiler berfungsi sebagai pesawat konversi energi yang mengkonversi energi kimia (potensial) dalam hal ini adalah bahan bakar menjadi energi panas. Boiler/ketel uap terdiri dari 2 komponen utama, yaitu:

- Dapur sebagai alat untuk mengubah energi kimia (bahan bakar) menjadi energi panas.

- Alat penguap (evaporator) yang mengubah energi pembakaran (energi panas) menjadi energi potensial uap (energi panas).

Boiler pada dasarnya terdiri dari tabung/bejana (drum) yang tertutup pada ujung pangkalnya, dan dalam perkembangannya dilengkapi di dalamnya pipa api maupun pipa air. Banyak orang mengklasifikasikan ketel uap tergantung pada sudut pandang masing-masing. Pada Pusat Pengembangan Sumber Daya Manusia Minyak dan Gas Cepu terdapat boiler type AL-LSB-6000 yang akan dirancang ulang bagian tube boilernya.

\section{B. Klasifikasi Ketel Uap (Boiler) Menurut Desain}

Menurut standar ASME boiler di golongkan menjadi dua, yaitu power boilers dan heating boilers.

- Power Boilers (Ketel Uap Daya) adalah ketel uap yang uap hasilnya digunakan diluar ketel dan memiliki tekanan uap lebih dari 15 Psi. Ketel uap ini didesain menggunakan standar ASME.

- Heating Boilers (Ketel Uap Pemanas). Boiler/ketel uap jenis ini memiliki tekanan uap berbanding terbalik dari Power Boiler yakni kurang dari 15 Psi. Boiler pemanas dirancang dengan aturan ASME Sec IV-Heating Boiler.

\section{Klasifikasi Ketel Uap Menurut Material}

Ketel uap juga diklasifikasikan berdasarkan banyaknya bahan material yang digunakan dalam proses pembuatannya [3]. Steel (baja) ketel uap ini, pada bagian utama dan bagian silinder terbuat dari baja. Cast Iron (Besi Tuang) ketel uap yang pada bagian utama serta silinder tekannya terbuat dari besi tuang (cast iron). Jenis Cast Iron Boiler (ketel uap besi tuang) dibedakan lagi menjadi dua, yaitu Horizontal-Section Cast Iron Boiler dan One Piece Cast Iron boiler. Pada jenis HorizontalSection Cast Iron Boiler, ketel uap dibuat menjadi beberapa bagian dan selanjutnya dilakukan perakitan. Jenis One Piece Cast Iron boiler, pada jenis ini bagian bejana tekan ketel uap dibuat pada satu cetakan/tidak dipisah

\section{Klasifikasi Ketel Uap Menurut Kegunaan}

1. Power Boiler (daya) adalah ketel uap yang digunakan sebagai pembangkit daya. Misalnya PLTU, PLTB, PLTG dan pembangkit listrik lainnya.

2. Process Boiler (proses), ketel uap ini digunakan pada industri pada suatu proses fabrikasi atau produksi.

3. Steam Heating (pemanas uap) jenis ketel uap ini dirancang pada tekanan kurang dari 15 Psi. Uap hasil pemanasan kemudian digunakan industri sebagai pemanas atau pengering pada suatu proses yang dibutuhkan.

4. Hot Water Heating (Pemanas Air Panas), ketel uap jenis ini digunakan untuk menjaga kondisi suhu air agar tetap sesuai dengan suhu yang dibutuhkan oleh suatu proses industri.

5. Hot Water Supply (Persediaan Air Panas) uap yang dihasilkan oleh ketel jenis ini hampir mirip dengan jenis ketel pemanas air panas diatas. Disini ketel digunakan untuk memanaskan air dan menjadi storage pada persediaan air panas.

6. Hot Water Heater (Pemanas Air). Ketel uap jenis ini memiliki tujuan yang sama dengan hot water heating boiler dan hot water supply boiler, namun memiliki perbedaan pada pengoperasian temperaturnya kurang dari $210 \mathrm{~F}$. 
E. Klasifikasi Ketel Uap Menurut Tube Type (Tipe Pipa) Berikut merupakan tipe-tipe tube boiler menurut klasifikasi tube type (tipe pipa) antara lain:

1. Ketel Uap Pipa Api (fire tube boiler)

Pada boiler pipa api yang dimana fluida yang mengalir dalam pipa adalah gas nyala yang membawa energi panas, yang segera mentransfer ke air melalui bidang pemanas [4]. Tujuan pipa-pipa api ini adalah untuk memudahkan distribusi panas pada air, seperti ditunjukkan pada Gambar 1.

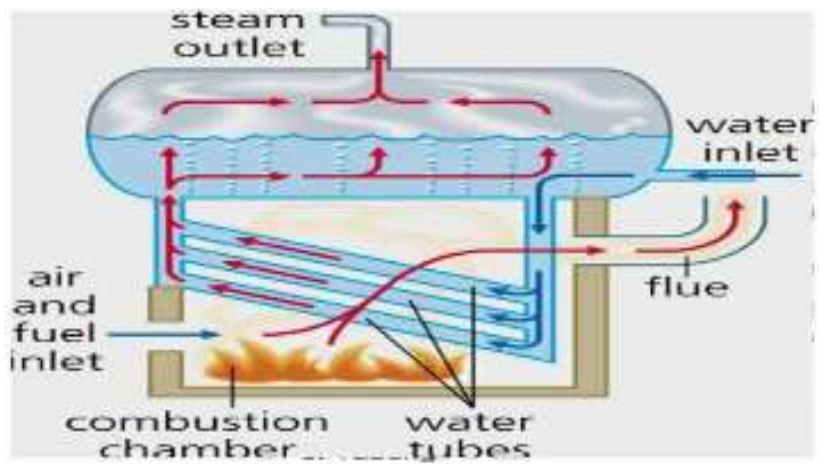

Gambar 1. Boiler Pipa Api

\section{Ketel Uap Pipa Air (water tube boiler)}

Pada boiler pipa air ini, fluida yang mengalir dalam pipa adalah air, energi panas ditransfer dari luar pipa (yaitu dari ruang bakar) ke air, seperti ditunjukkan pada Gambar 2.

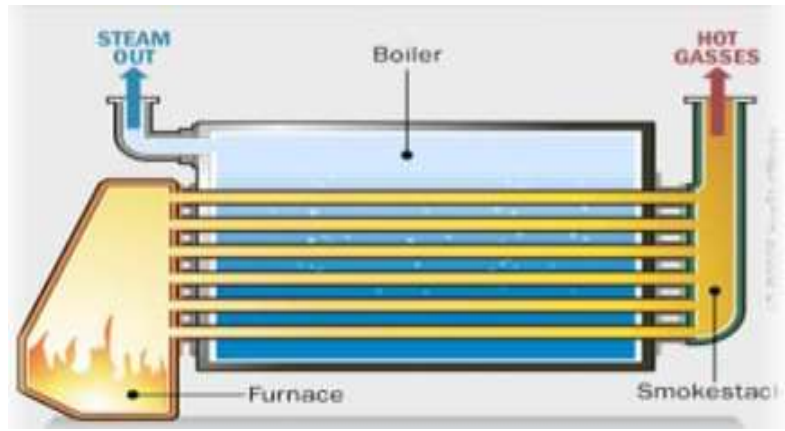

Gambar 2. Boiler Pipa Air

\section{F. Perhitungan Boiler}

Perancangan boiler, pertama menentukan tekanan tekanan yang bekerja pada struktur boiler. Untuk menentukan ketebalan pada struktur boiler harus mengetahui spesifikasi material yang akan digunakan. Struktur boiler yang akan dihitung yaitu tebal badan boiler, pipa api (fire tube), Flat heads (heating plate), tubesheet, ligament dan nosel-nosel pipa.

\section{Badan Boiler}

Jenis boiler yang dipilih dari jenis boiler pipa api (fire tube). Boiler pipa api (fire tube boiler) bekerja dengan pipa-pipa api yang berada didalam silinder tabung. Pemanasan dihasilkan dari pembakaran residu di ruang bakar dan menyalurkan panas melalui pipa api. Air berada disekitar permukaan pipa api, selanjutnya temperatur air naik dan menghasilkan uap air yang disalurkan ke tempat perebusan. Boiler yang akan dirancang merupakan boiler dengan kapasitas kecil, sehingga material - material dalam merencanakan boiler ini disesuaikan dengan kebutuhan. Badan boiler bekerja dengan mendapatkan tekanan dari dalam (Parts under Internal Pressure). Dalam badan boiler ini terdapat tube boiler yang ingin dirancang dan ingin diganti material dari tube boiler tersebut.

2. Pipa Api (Fire Tube)

Pipa api merupakan bagian alat penguapan (evaporator) yang mengubah energi pembakaran (energi panas) menjadi energi potensial uap, yaitu panas dari api memanaskan air dan menjadi uap air. Pipa api bekerja dengan mendapatkan gaya tekan dari luar (Parts Under External Pressure). Pipa api juga merupakan salah satu tipe pipa yang mengalirkan panas hasil proses pembakaran ke dalam satu atau lebih pipa-pipa yang berada di dalam wadah tertutup berisi air. Berbagai desain saluran pipa berbeda dibuat untuk memkasimalkan penyerapan panas dari gas buang hasil pembakaran gas buang tersebut. Level air di dalam tanki boiler, wajib terjaga ketinggiannya untuk menjaga atau menghindari dari overheat.

\section{Tubesheet}

Pipa api pada boiler fire tube digunakan dengan pemasangan yang tetap. Tubesheet adalah tempat untuk menopang pipa - pipa api pada boiler. Ketebalan yang dibutuhkan, maksimal jarak antar pipa api, dan tekanan perancangan untuk tubesheet dengan pipa api yang digunakan dengan pemasangan tetap.

\section{Ligament}

Ligament adalah jarak plat antar lubang pipa api pada tubesheet. Pengaturan pengaplikasian ligament untuk bukaan silinder bertekanan (cylindrical-pressure) disesuaikan dengan pola yang akan digunakan, seperti pada Gambar 3, yakni pola jarak lubang tubesheet yang sama pada setiap baris.

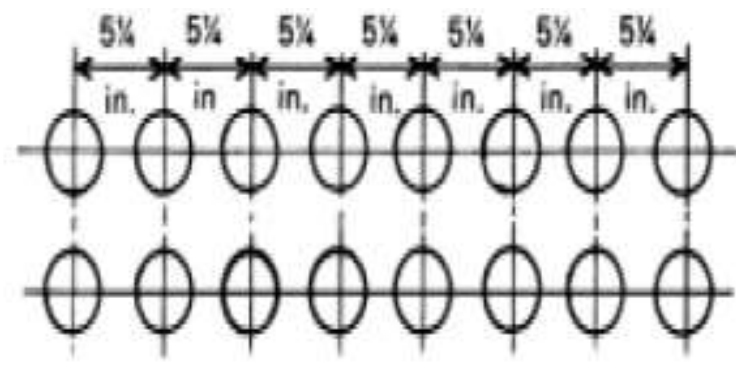

Longitudinal Line

Gambar 3. Pola jarak lubang tubesheet yang sama pada setiap baris. 


\section{G. ASME (American Society Mechanical Engineering)}

ASME adalah organisasi dengan standar tertua di Amerika. ASME menghasilkan sekitar 600 kode dan standar yang mencakup banyak area teknis seperti perlengkapan pipa, lift, jaringan pipa, dan sistem pembangkit dan komponennya. Standar ASME dikembangkan oleh komite ahli materi pelajaran yang menggunakan proses berbasis konsensus terbuka. Banyak standar ASME yang dikutip oleh instansi pemerintah sebagai alat untuk memenuhi tujuan mereka. Standar ASME digunakan di lebih dari 100 negara di dunia dan diterjemahkan ke dalam berbagai bahasa. ASME berdiri pada tahun 1880 oleh Alexander Lyman Holley, Henry Rossiter Worthington, John Edison Sweet dan Matthias N. Forney sebagai jawaban atas berbagai kegagalan dalam permasalahan tekanan uap boiler. ASME membentuk sebuah komite pada tahun 1911 untuk merumuskan aturan/prosedur perancangan ketel uap dan bejana bertekanan yang kemudian dikenal sebagai komite ASME Boiler and Pressure Vessel. Komite ini mengikuti prosedur terakreditasi oleh ANSI (American National Standart Institute). Pada kode ASME Boiler \& Pressure Vessel mengandung 11 bagian:

1. Bagian I - Power Boilers

2. Bagian II - Material Specifications

- Bagian A, Spesifikasi Bahan Fe Bagian ini menyediakan spesifikasi material untuk bahan bahan besi yang cocok untuk digunakan dalam konstruksi bejana tekan.

- Bagian B, Spesifikasi Bahan Non Fe Bagian ini menyediakan spesifikasi material untuk bahan nonferrous / non besi yang cocok untuk digunakan dalam pembangunan pembuluh tekanan. Spesifikasi Bagian ini menentukan sifat mekanik, perlakuan panas, panas dan komposisi dan analisis kimia produk, spesimen uji, dan metodologi pengujian.

- Bagian C, Spesifikasi khusus Pengelasan, Elektroda Bagian ini memberikan sifat mekanik, perlakuan panas, analisis spesimen uji, komposisi kimia produk, metodologi pengujian batang las, elektroda yang digunakan dan logam pengisi dalam pembangunan pembuluh tekanan.

3. Bagian III - Rules for Construction of Nuclear Power Plant Components

4. Bagian IV - Heating Boilers

5. Bagian V - Nondestructive Examination

6. Bagian VI - Recommended Rules for Care and Operation of Heating Boilers

7. Bagian VII - Recommended Rules for Care of Power Boilers

8. Bagian VIII - Pressure Vessels

9. Bagian IX - Welding and Brazing Qualifications

10. Bagian X - Fiber-Reinforced Plastic Pressure Vessels

11. Bagian XI - Rules for In-Service Inspection of Nuclear Power Plant Components

Bagian, I, II, III, IV, V, VIII, IX, dan XI menetapkan suatu aturan dan persyaratan untuk pipa. Bagian II, V, dan IX adalah bagian tambahan dari 13 kode karena mereka tidak memiliki yurisdiksi mereka sendiri kecuali dipanggil oleh referensi dalam kode rekaman untuk konstruksi, seperti Bagian I atau III [5].

\section{H. Uap (steam)}

Uap air adalah jenis fluida yang merupakan fase gas dari air, yang mengalami pemanasan sampai temperatur didih dibawah tekanan tertentu. Uap air tidak berwarna, bahkan tidak terlihat bila dalam keadaan murni kering. Uap air dipakai pertama sekali sebagai fluida kerja oleh James Watt yang terkenal sebagai penemu mesin uap torak. Uap air tidak mengikuti hokum gas sempurna, sampai dia benar-benar kering (kadar uap 100\%) [2]. Bila uap air kering dipanaskan lebih lanjut maka dia menjadi uap air panas (panas lanjut) dan selanjutnya dianggap sebagai gas sempurna.

Uap air terbentuk dalam tiga jenis, yaitu:

- uap saturasi basah,

- uap saturasi kering,

- uap air panas

Dalam pemenuhan steam di dalam proses pengolahan di kilang PPSDM Migas Cepu, saat ini di operasikan satu unit boiler AL-LSB-6000 yang dapat menghasilkan superheated steam, yang ditunjukkan pada Gambar 4, diagram superheated steam.

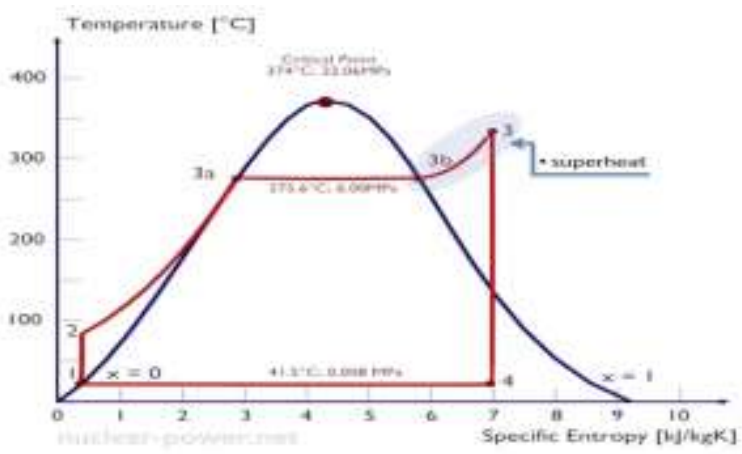

Gambar 4. Diagram superheated steam

\section{Heat Exchanger Tipe Tubular}

Heat exchanger tipe ini melibatkan penggunaan tube pada desainnya. Bentuk penampang tube yang digunakan bisa bundar, elips, kotak, twisted, dan lain sebagainya. Heat exchanger tipe tubular didesain untuk dapat bekerja pada tekanan tinggi, baik tekanan yang berasal dari lingkungan kerjanya maupun perbedaan tekanan tinggi antar fluida kerjanya. [6] Tipe tubular sangat umum digunakan untuk fluida kerja cair-cair, cair-uap, cair-gas, ataupun juga gas-gas, khusus untuk digunakan pada kondisi fluida kerja bertekanan dan bertemperatur tinggi sehingga tidak ada jenis heat exchanger lain yang mampu untuk bekerja pada kondisi tersebut. Berikut adalah beberapa jenis heat exchanger tipe tubular:

1. Shell \& Tube

Heat exchanger tipe shell \& tube menjadi satu tipe yang paling mudah dikenal. Tipe ini melibatkan tube 
sebagai komponen utamanya. Salah satu fluida mengalir di dalam tube, sedangkan fluida lainnya mengalir di luar tube. Pipa-pipa tube didesain berada di dalam sebuah ruang berbentuk silinder yang disebut dengan shell, sedemikian rupa sehingga pipa-pipa tube tersebut berada sejajar dengan sumbu shell.

\section{Double Pipe}

Heat exchanger ini menggunakan dua pipa dengan diameter yang berbeda. Pipa dengan diameter lebih kecil dipasang paralel di dalam pipa berdiameter lebih besar. Perpindahan panas terjadi pada saat fluida kerja yang satu mengalir di dalam pipa diameter kecil, dan fluida kerja lainnya mengalir di luar pipa tersebut. Arah aliran fluida dapat didesain berlawanan arah untuk mendapatkan perubahan temperatur yang tinggi, atau jika diinginkan temperatur yang merata pada semua sisi dinding heat exchanger maka arah aliran fluida dapat didesain searah.

\section{Spiral Tube}

Heat exchanger tipe ini menggunakan pipa tube yang didesain membentuk spiral di dalam sisi shell. Perpindahan panas pada tipe ini sangat efisien, namun di sisi hampir tidak mungkin untuk melakukan pembersihan sisi dalam tube apabila kotor. Spiral tube ini berbentuk spiral.

\section{J. Analisis Aliran Internal}

Setelah menganalisa metode LMTD maka analisis selanjutnya yang dilakukan adalah menganalisa aliran internal atau aliran feedwater dalam tube. Analisis ini dilakukan untuk mendapatkan dimensi tube, kecepatan optimal dalam tube, jumlah tube yang dibutuhkan dan besarnya koefisien konveksi dalam tube [7]. Beberapa data tube telah diketahui dari HPH 2 sebelumnya.

Dengan memvariasikan kecepatan dalam tube maka akan dapat kita tentukan kecepatan optimal dalam tube. Semakin tinggi kecepatan dalam tube maka perpindahan panas yang terjadi semakin tinggi tetapi seiring dengan meningkatnya koefisien perpindahan panas pressure drop yang terjadi semakin tinggi pula. [8] Oleh karena itu perlu ditentukan besarnya kecepatan aliran dalam tube yang paling optimal dengan nilai pressure drop yang masih memenuhi batas toleransi, yaitu kurang dari 0,7 bar.

Aliran turbulen merupakan aliran dengan pola yang random dan kacau yang mengandung ketidakstabilan aliran didalamnya. Sedangkan lawan kata dari turbulen adalah laminar, yaitu aliran dengan pola yang halus dan terprediksi tanpa adanya gangguan atau path. Pada aliran yang laminar terkadang mudah untuk diseleseikan misalkan disederhanakan menjadi persamaan bernaoulli.

\section{K. Getaran (Vibrasi)}

FIV (Flow Induced Vibration) bisa disebabkan karena adanya sesuatu yang dapat merubah aliran laminar menjadi aliran turbulen. Aliran turbulen inilah yang menyebabkan pipa mengalami vibrasi (getaran). Getaran adalah suatu gerakan bolak-balik yang mempunyai amplitudo yang sama [9]. Getaran juga dapat disebabkan oleh fluida yang mengalir pada saat boiler bekerja, yaitu mengalir melalui tube boiler yang berupa cairan ataupun gas panas. Getaran gerakan yang terjadi secara bolakbalik di sekitar kesetimbangan. Syarat terjadinya getaran adalah benda menglami kondisi diam ketika tiak menerima gaya gerak, selain itu jarak simpangan terjauh secara bolak-balik akibat getaran selalu sama apabila diukur dari tengah. Ada beberapa jenis getaran yaitu getaran bebas dan getaran paksa. Getaran bebas terjadi bila sistem mekanis dimulai dengan gaya awal lalu dibiarkan bergetar secara bebas. Contoh getaran seperti ini adalah memukul garpu tala dan membiarkannya bergetar atau bandul yang ditarik lalu dilepaskan dalam keadaan setimbang. Getaran paksa terjadi bila gaya bolak-balik atau gerakan diterapkan pada sistem mekanis. Contohnya adalah aliran fluida yang mengalir pada tube boiler. Beberapa komponen penting pada getaran adalah sebagai berikut:

1. Frekuensi

Frekuensi adalah banyaknya jumlah putaran atau gerakan dalam satu satuan waktu. Dinyatakan dalam satuan Hertz (Hz).

\section{Amplitudo}

Amplitudo adalah simpangan terbesar dari titik normalnya. Amplitudo dapat berupa:

- Perpindahan (displacement).

- Kecepatan (velocity).

- Percepatan (acceleration).

- Sudut fase (Phase angle).

Sudut fase dapat diartikan seagai perbedaan amplitude dalam satu frekuensi [10]. Analisa vibrasi dapat di definisikan sebagai studi dari pergerakan osilasi, dengan tujuan mengetahui efek dari vibrasi dalam hubungannya dengan performance dan keamanan sebuah sistem dan bagaimana mengontrolnya. Deskripsi sederhana merupakan suatu frekuensi atau getaran yang disebabkan oleh suatu fluida yang dialami pada tube boiler. Pada boiler type AL-LSB-6000 yang dirancang ulang tubenya pada penelitian ini terdapat aliran laminar yang dimana menyebabkan suatu getaran diakibatkan dari aliran laminar tersebut, tetapi tidak terjadi getaran yang parah dan menyebabkan suatu kerusakan yang parah karena getarannya tidak besar, seperti ditunjukkan pada Gambar 5, deskripsi vibrasi sederhana. 




Gambar 5. Deskripsi vibrasi sederhana

\section{METODE PENELITIAN}

Pelaksanaan kegiatan perencenaan tube boiler type $A L-L S B-6000$ ini melalui tahapan-tahapan yang harus dilalui sebelum melakukan analisa dan mendapatkan hasil yang direncanakan, dan berikut ini merupakan tahapan guna mencapai tujuan yang diharapkan, seperti ditunjukkan pada Gambar 6.

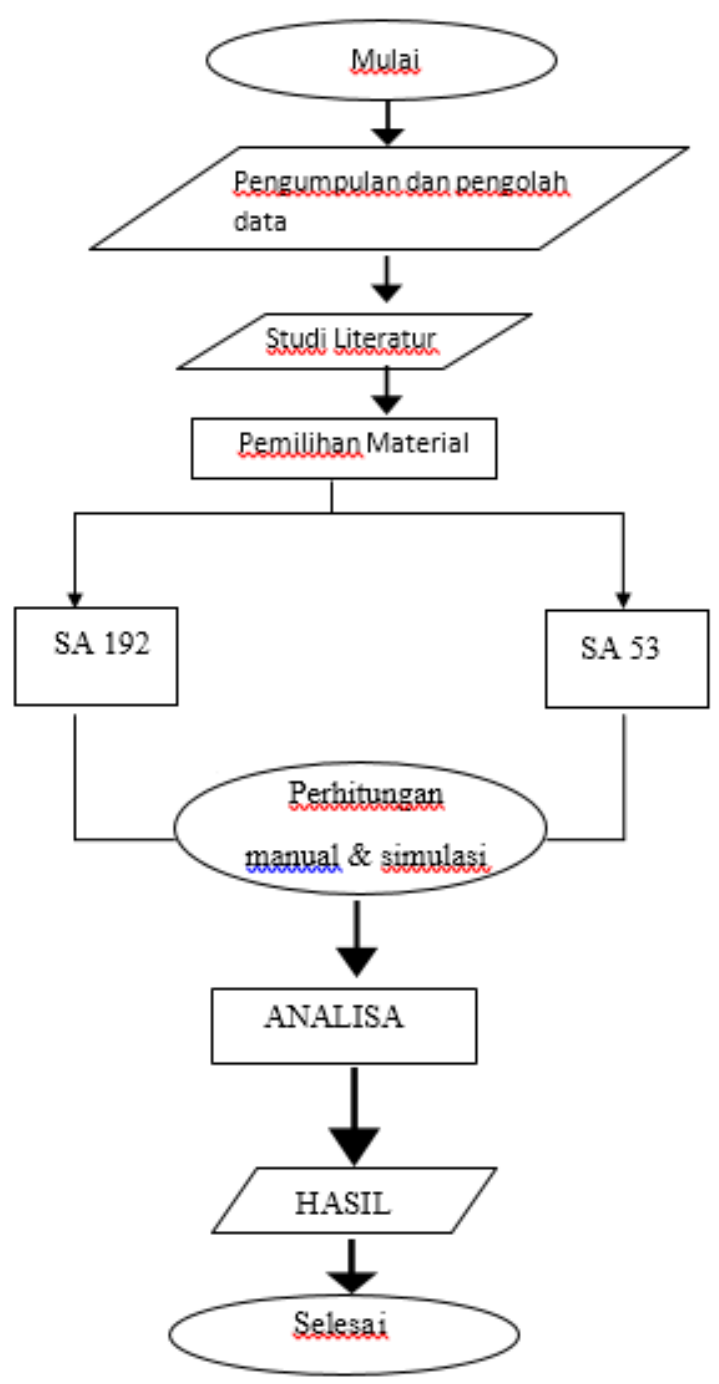

Gambar 6. Diagram alir penelitian

Penjelasan Diagram Alir Perencanaan

1. Langkah pertama dalam perancangan tugas akhir ini adalah mencari literatur yang berhubungan dengan boiler jurnal, skripsi, Jurnal dan Text Book.

2. Langkah kedua adalah mempelajari data-data yang telah dikumpulkan.

3. Langkah ketiga adalah memilih atau menentukan material yang digunakan dalam kontruksi tube boiler type $A L-L S B-6000$. Material ini dapat ditentukan dengan membedakan material boiler yang sudah ada sebelumnya di PPSDM Migas Cepu, dengan material baru yaitu SA 53.

4. Langkah keempat adalah melakukan perhitungan manual dan simulasi pada tube boiler type $A L-L S B-$ 6000 dengan menggunakan simulasi software.

5. Langkah kelima adalah menganalisa hasil dari perhitungan manual dan simulasi pada software serta mendapatkan hasil perbandingan antara material SA 192 dengan material SA 53.

6. Langkah keenam adalah menunjukkan hasil dari analisa yang telah dilakukan.

\section{PERHITUNGAN DAN ANALISIS}

\section{A. Spesifikasi Boiler}

Desain boiler yang telah didapatkan merupakan hasil dari pengumpulan data dari literatur, survei lapangan dan perhitungan-perhitungan yang telah dilakukan. Spesifikasi perancangan bangun boiler menggunakan parameter-parameter sebagai berikut:

Tipe boiler

Diameter dalam badan boiler

Diameter luar pipa api

Tebal pipa api

Panjang pipa api

Teknanan perancangan

Jenis uap

Tekanan operasi

Bahan bakar

Material tubes

Berikut merupakan gambar ditunjukkan pada Gambar 7.

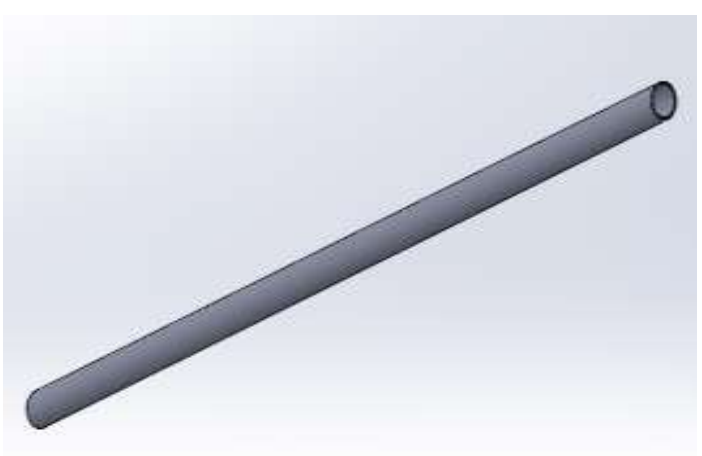

Gambar 7. Desain pipa api

B. Perhitungan tentang tegangan pada material tube

Dengan menggunakan material SA 192 untuk material pipa:
: Fire tube boiler

: $1950 \mathrm{~mm}$

: $63,5 \mathrm{~mm}$

: $3,2 \mathrm{~mm}$

: $4500 \mathrm{~mm}$

$: 12 \mathrm{~kg} / \mathrm{cm}^{2}=12 \mathrm{bar}$

: Uap jenuh

$: 10 \mathrm{~kg} / \mathrm{cm}^{2}=10 \mathrm{bar}$

: Residu

: SA 192

desain tube boiler 


$$
\begin{aligned}
S h & =\frac{P_{\text {do }}}{2 . t}=\frac{12 \mathrm{~kg} / \mathrm{cm}^{2} \times 6,35 \mathrm{~cm}}{2 \times 0,32 \mathrm{~cm}} \\
& =119,06 \mathrm{~kg} / \mathrm{cm}^{2}
\end{aligned}
$$

Bila dikonversikan ke satuan Pascal dari 119,06 $\frac{\mathrm{kg}}{\mathrm{cm}^{2}}$ maka mendapatkan nilai sebesar 11675797,49 Pascal atau $11,67 \mathrm{Mpa}$.

\section{Simulasi Tube boiler}

Perhitungan Tube Boiler menggunakan software ANSYS 17.0. Kegunaan dari perhitungan sebagai data pembanding dengan hasil data yang didapat dengan hasil perhitungan teori, karena didapatkan perbedaan antara kedua hasil tersebut maka simulasi ditujukan sebagai referensi tambahan untuk mendukung hasil dari perhitungan teori. Adapun langkah dalam pengerjaan simulasi dengan menggunakan software ANSYS 17.0 adalah sebagai berikut:

1. Langkah pertama yaitu merancang tube boiler SA 192 dengan menggunakan parameter-parameter yang telah ada seperti berikut:

- diameter luar : $63,5 \mathrm{~mm}$

- tebal : $3,2 \mathrm{~mm}$

- panjang : $4500 \mathrm{~mm}$

- temperatur : $184 \mathrm{C}$

- tekanan : 12 bar

2. Langkah kedua mengatur geometry dimana dalam hal ini nama dari bagian benda atau objek yang akan disimulasikan diganti sesuai yang kita kehendaki. Benda atau objek terlebih dahulu digambarkan pada Solidworks, kemudian diimport ke ANSYS 17.0. Pada bagian ini ditentukan juga mana bagian yang bertindak sebagai fluida dan solid, seperti ditunjukkan pada Gambar 8.

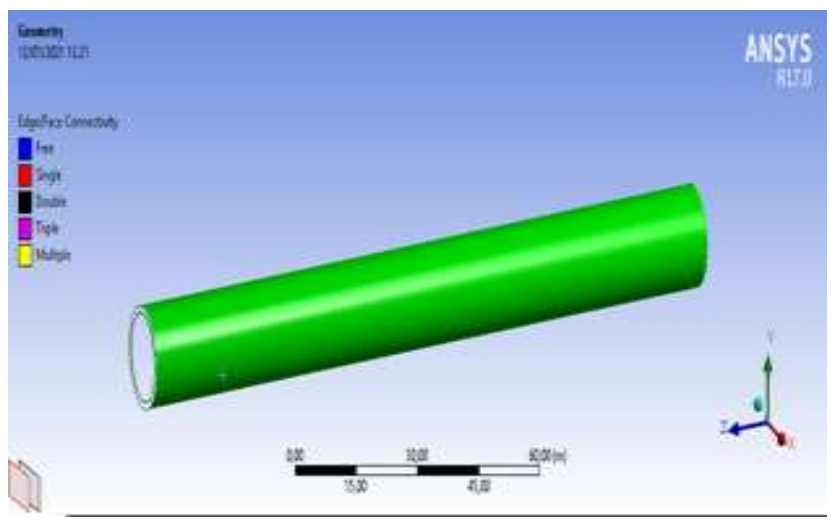

Gambar 8. Mengatur geometry

3. Langkah ketiga mengatur mesh atau bidang sebagai referensi kita dalam menganalisis, dalam hal ini diatur nama dari bagian yang akan dianalisa dalam hal ini diatur nama dari bagian yang akan dianalisa dalam hal ini parameter yang dimasukan yaitu isolasi, air panas masuk dan keluar serta air dingin masuk dan keluar, seperti ditunjukkan pada Gambar 9.

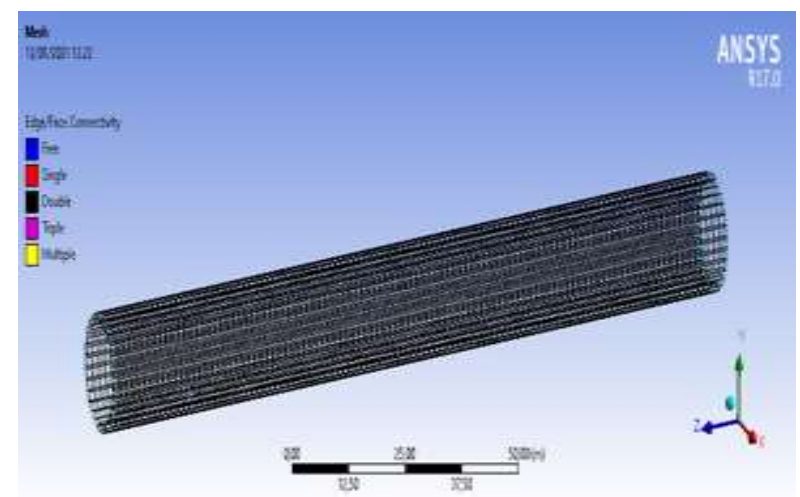

Gambar 9. Mengatur mesh

4. Langkah selanjutnya setelah geometry dan mesh diatur langkah selanjutnya adalah mengatur setup. Akan tetapi terlebih dahulu kita check quality. Untuk mengecek kualitas dari aliran yang masuk kedalam tube boiler apakah aliran tersebut bersih atau tidak, seperti ditunjukkan pada Gambar 10.

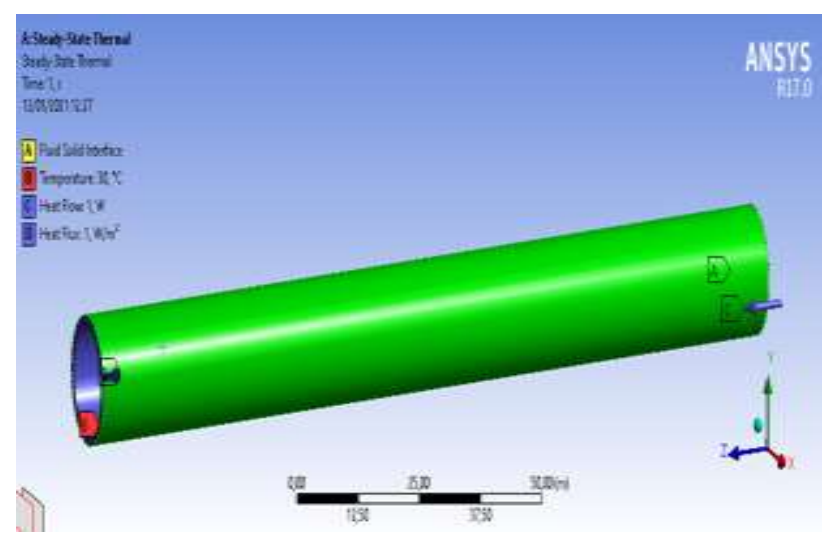

Gambar 10. Hasil pengecekan dan display mesh

5. Langkah selanjutnya, kemudian mengatur metode perhitungan yang akan dikerjakan. Pada model diatur energi pada posisi on, seperti pada Gambar 11.

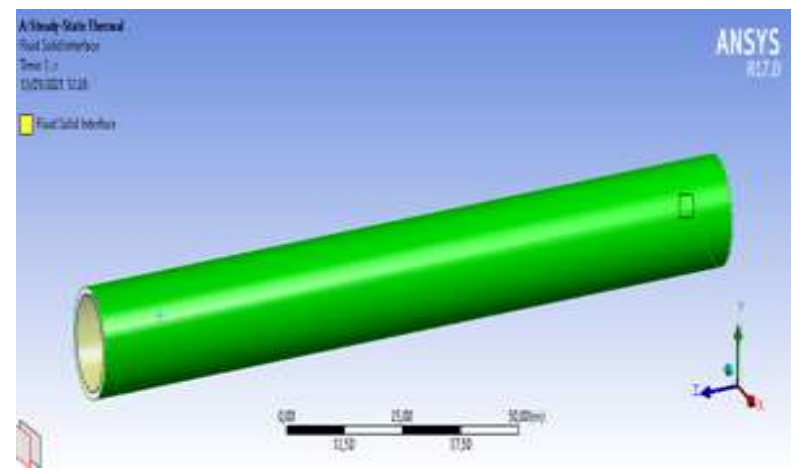

Gambar 11. Mengatur set up

6. Setelah itu diatur temprature sesuai dengan kondisi fluida (aliran laminar, turbulen, atau transisi), seperti ditunjukkan pada Gambar 12. 


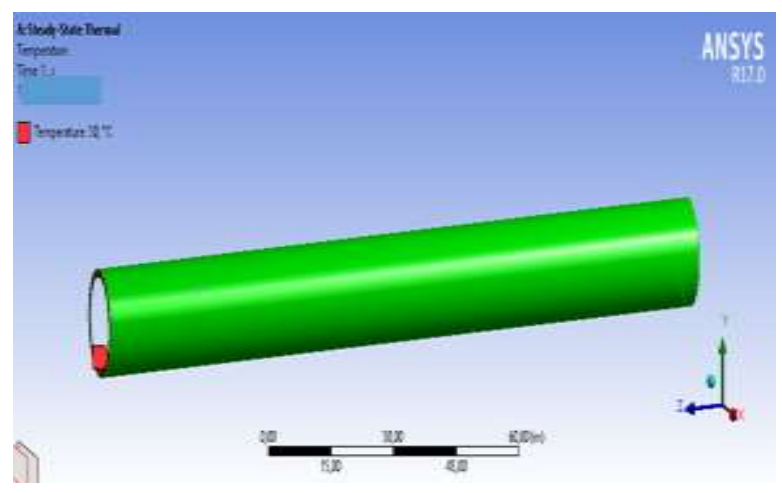

Gambar 12. Mengatur viscous

7. Selanjutnya diatur heat flux sesuai dengan kondisi yang telah ditentukan, seperti ditunjukkan pada Gambar 13.

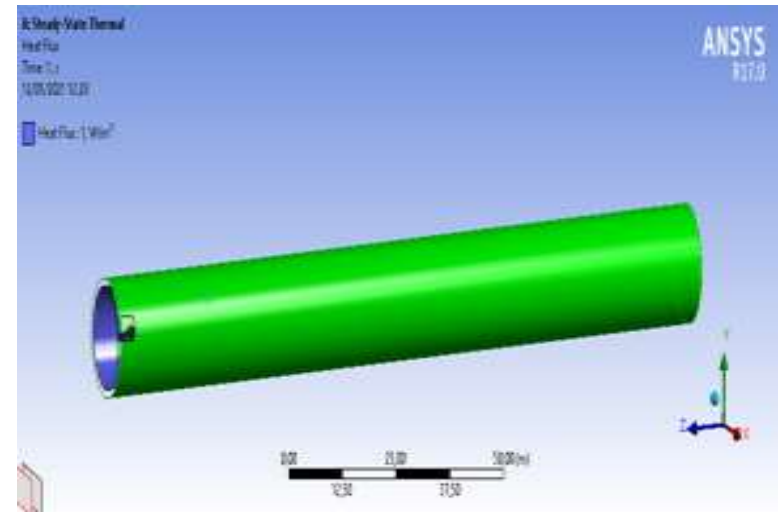

Gambar 13. Mengatur setup heat flux.

8. Pada bagian stress didapatkan nilai pada tegangan pipa saat air mengalir setelah itu diatur berapa suhu masuk beserta kecepatan fluida masuk ke dalam software ANSYS 17.0, seperti ditunjukkan pada Gambar 14.

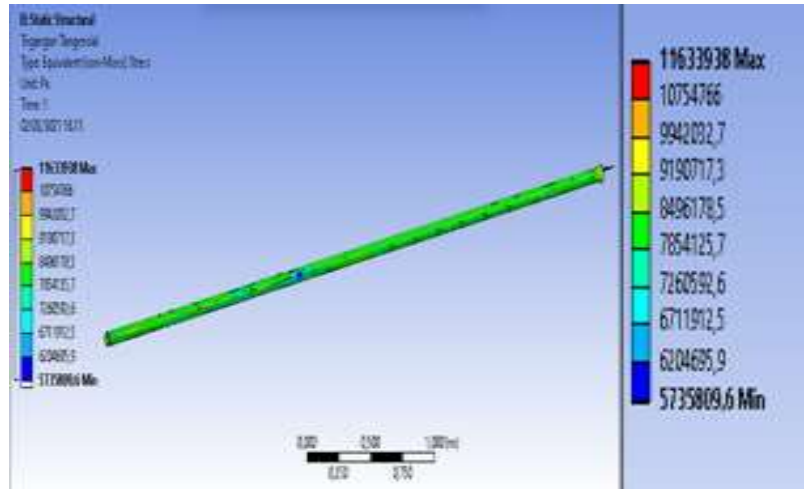

Gambar 14. Stress

Nilai yang di dapatkan pada 11633938 Pascal atau 11,63 Mpa yang didapatkan pada perhitungan simulasi FEA, sedangkan pada perhitungan manual diperoleh 11675797,49 Pascal atau 11.67 Mpa, sehingga diperoleh nilai hasil perhitungan manual hampir mendekati nilai yang diperoleh pada simulasi.

\section{Perbandingan perhitungan material SA 53}

Berdasarkan material sebelumnya yaitu SA 192 yang terdapat atau dipakai pada boiler sebelumnya untuk merancang tube boiler type AL-LSB-6000 pada Pusat Pengembangan Sumber Daya Manusia Minyak dan Gas Cepu didapatkan dimensi seperti yang sudah di jelaskan pada penjelasan sebelumnya, dibawah ini merupakan tabel spesifikasi material SA 53 yang diperoleh dari [11]. Pada tabel tersebut didapatkan dimensi dari tube yaitu diameter luar tube sebesar $60,3 \mathrm{~mm}$ dan tebal dari tube sebesar 3,91 mm. Digunakannya material SA 53 karena material ini memiliki daya tahan tegangan lebih besar dibanding material sebelumnya dan juga dimensi dari pipa ini berbeda dengan dimensi sebelumnya, yang menyebabkan diameter pipa ini sedikit lebih kecil. Oleh karena itu adanya semakin besar atau celah dari pipa satu ke pipa lainnya yang membuat proses pemanasan fluida akan lebih banyak masuk dan mempercepat proses pemanasan sehingga menghemat waktu proses pemanasan yang mana lebih cepat dari waktu sebelumnya. Lebih jelasnya ditunjukkan pada Gambar 15.

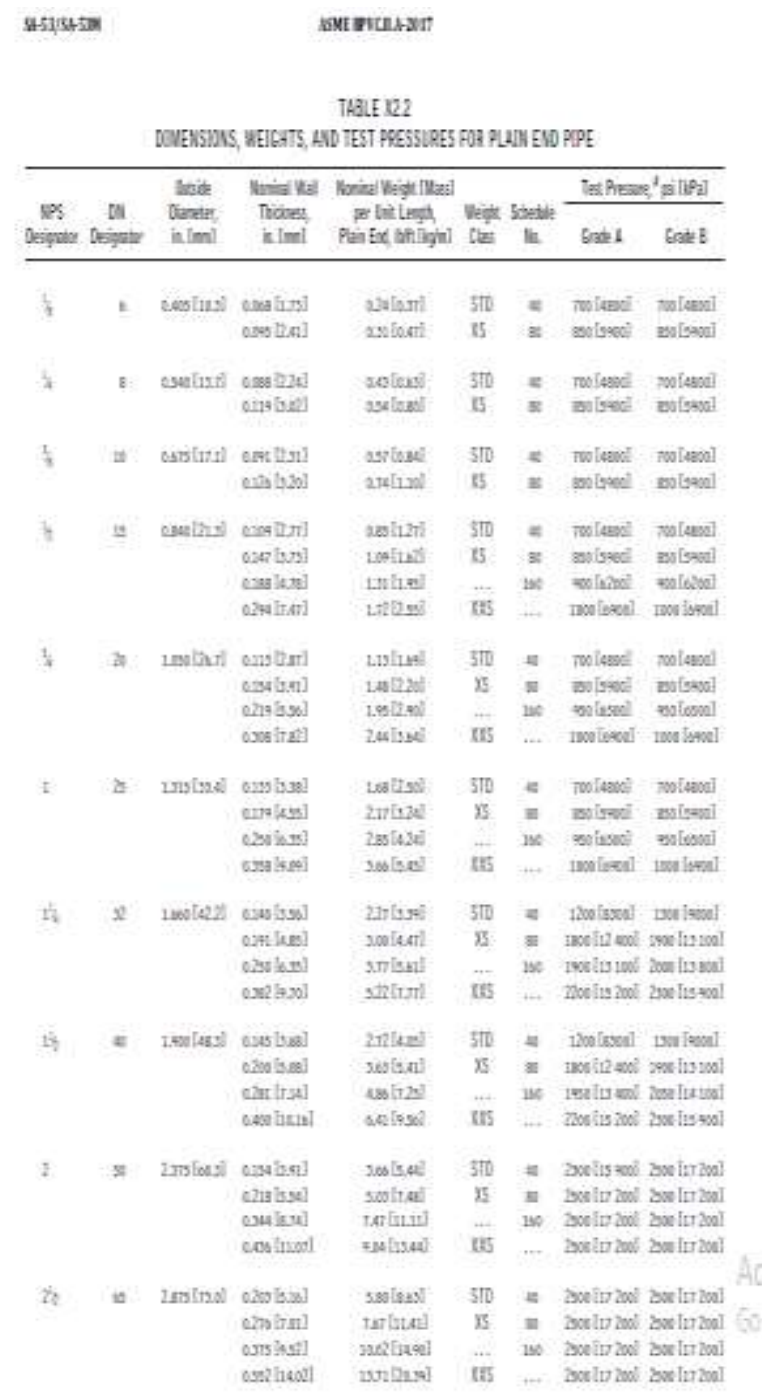

Gambar 15. Spesifikasi material SA 53 
Selanjutnya menggunakan material SA 53 untuk bahan pipa dengan parameter-parameter yang tepat sama dengan yang ditetapkan untuk material SA 192, maka akan menghasilkan perhitungan sebagai berikut:

$$
\begin{aligned}
& S h=\frac{P \text { do }}{2 \cdot t} \\
& =\frac{12 \frac{\mathrm{kg}}{\mathrm{cm}^{2}} \times 6,03 \mathrm{~cm}}{2 \times 0,39 \mathrm{~cm}} \\
& =92,76 \mathrm{~kg} / \mathrm{cm}^{2}
\end{aligned}
$$

Atau 9096648,54 Pascal (9,09 Mpa).

\section{E. Perhitungan menggunakan simulasi}

Perancangan tube boiler SA 53 dengan memasukkan parameter-parameter yang tepat sama dengan parameterparameter pada SA 192. Hasil simulasi pipa SA 53 ditunjukkan pada Gambar 16.



Gambar 16. Simulasi pipa SA 53

F. Perhitungan gaya tekan pada tube

Pada perhitungan gaya tekan bisa dihitung dengan perbandingan antara material SA 192 dengan material SA 53 sebagai berikut.

1. Gaya tekan ke atas pada tube SA 192

$P=\frac{F}{A}$

$F=P . A$

$=12 \mathrm{Kg} / \mathrm{cm}^{2} \times \pi d(r+t)$

$=12 \mathrm{Kg} / \mathrm{cm}^{2} \times 3,14.6,03 \mathrm{~cm}(3,17 \mathrm{~cm}+150 \mathrm{~cm})$

$=12 \mathrm{Kg} / \mathrm{cm}^{2} \times 3054,05 \mathrm{~cm}^{2}$

$=36648,67 \mathrm{~kg}$

$=366486,72 \mathrm{~N}$

2. Gaya tekan ke bawah pada tube SA 192

$P=\frac{F}{A}$

$F=P \cdot A$

$$
\begin{aligned}
& =12 \mathrm{Kg} / \mathrm{cm}^{2} \times \pi d(r+t) \\
& =12 \mathrm{Kg} / \mathrm{cm}^{2} \times 3,14.6,03 \mathrm{~cm}(3,17 \mathrm{~cm}+150 \mathrm{~cm}) \\
& =12 \mathrm{Kg} / \mathrm{cm}^{2} \times 3054,05 \mathrm{~cm}^{2} \\
& =36648,67 \mathrm{~kg} \\
& =366486,72 \mathrm{~N}
\end{aligned}
$$

3. Gaya tekan ke atas pada tube SA 53

$P=\frac{F}{A}$

$F=P \cdot A$

$=12 \mathrm{Kg} / \mathrm{cm}^{2} \times \pi d(r+t)$

$=12 \mathrm{Kg} / \mathrm{cm}^{2} \times 3,14 \cdot 6,03 \mathrm{~cm}(3,01 \mathrm{~cm}+150 \mathrm{~cm})$

$=12 \mathrm{Kg} / \mathrm{cm}^{2} \times 2897,21 \mathrm{~cm}^{2}$

$=34766,59 \mathrm{~kg}$

$=347665,99 \mathrm{~N}$

4. Gaya tekan ke bawah pada tube SA 53

$P=\frac{F}{A}$

$F=P . A$

$=12 \mathrm{Kg} / \mathrm{cm}^{2} \times \pi d(r+t)$

$=12 \mathrm{Kg} / \mathrm{cm}^{2} \times 3,14.6,03 \mathrm{~cm}(3,01 \mathrm{~cm}+150 \mathrm{~cm})$

$=12 \mathrm{Kg} / \mathrm{cm}^{2} \times 2897,21 \mathrm{~cm}^{2}$

$=34766,59 \mathrm{~kg}$

$=347665,99 \mathrm{~N}$

Hasil perhitungan gaya tekan ke atas dan ke bawah sama karena diameter tube sama juga dan panjang antara baffle/base frame dengan baffle/base frame yang lainnya juga sama.

\section{G. Analisis}

Berdasarkan perhitungan pada perhitungan manual yang mengacu pada standar ASME (American Society of Mechanical Enginering) yang selanjutnya dilakukan simulasi menggunakan software ANSYS 17.0 didapatkan hasil sebagai berikut:

a. Perhitungan manual

- Hasil perhitungan manual tegangan tube SA 192 yakni $119,06 \mathrm{~kg} / \mathrm{cm}^{2}=11,67 \mathrm{Mpa}$

- Hasil perhitungan manual tegangan tube SA 53 yakni $92,76 \mathrm{~kg} / \mathrm{cm}^{2}=9,09 \mathrm{Mpa}$

- Gaya tekan ke atas pada tube SA $192=$ $366486,72 \mathrm{~N}$

- Gaya tekan ke bawah pada tube SA $192=$ $366486,72 \mathrm{~N}$

- Gaya tekan ke atas pada tube SA $53=$ $347665,99 \mathrm{~N}$

- Gaya tekan ke bawah pada tube SA $53=$ $347665,99 \mathrm{~N}$

b. Perhitungan simulasi ANSYS 17.0 
- Hasil perhitungan tegangan tube SA $192=11,63$ Mpa

- Hasil perhitungan tegangan tube SA $53=9,14$ Mpa

Tegangan yang terjadi di material tube SA 192 lebih besar dibanding dengan tegangan yang terjadi di material SA 53. Gaya tekan tube SA192 lebih besar dibanding dengan gaya tekan yang dihasilkan SA53, sehingga disarankan untuk mengganti material SA 192 menjadi material SA 53.

\section{KESIMPULAN}

Berdasarkan perhitungan pada perhitungan manual yang mengacu pada standar ASME (American Society of Mechanical Enginering) yang selanjutnya dilakukan simulasi menggunakan software ANSYS 17.0 didapatkan kesimpulan sebagai berikut:

Perhitungan material SA 192

- Hasil perhitungan manual tegangan tube SA 192 yakni $119,06 \mathrm{~kg} / \mathrm{cm}^{2}=11,67 \mathrm{Mpa}$

- Hasil perhitungan simulasi tegangan tube SA $192=$ $11,63 \mathrm{Mpa}$

Perhitungan material SA 53

- Hasil perhitungan manual tegangan tube SA 53 yakni $92,76 \mathrm{~kg} / \mathrm{cm}^{2}=9,09 \mathrm{Mpa}$

- Hasil perhitungan simulasi tegangan tube SA $53=$ 9,14 Mpa

Tegangan yang terjadi di material tube SA 192 lebih besar dibanding dengan tegangan yang terjadi di material SA 53. Gaya tekan tube SA192 lebih besar dibanding dengan gaya tekan yang dihasilkan SA53, sehingga disarankan untuk mengganti material SA 192 menjadi material SA 53.

\section{REFERENSI}

[1] W. D. Raharjo dan Karnowo, Mesin konversi energi, Jurnal Teknik Mesin UNNES, 2(8), 2008, 1-7.

[2] Shofiudin, M., \& Al-janan, D. H, Water tube boiler industri kecil tahu, Perancangan Pabrik Industri Modern, 4(7), 2019, 189-210.

[3] Wening Kusuma, P. T. W, \& Rachbini, D. J. Simulasi Kebijakan Penambahan Areal Tanam dan Peningkatan Produktivitas dalam Mendukung Tercapainya Swasembada, 2019. [online]. URL: http://peningkatanproduktivitasdalammendukungtercapain yaswasembada.com, diakses tanggal 18 Desember 2020.

[4] Dwi Ardiyanto Effendy. Rancang bangun boiler untuk proses pemanasan sistem uap pada industri tahu dengan menggunakan Catia V5, Jurnal Teknik Mesin UNNES, 3(4), 2013, 1-8.

[5] ASME, Boiler \& Pressure Vessel Code IV, Ruleforor construction for heating boiler. New York: Three Park Avenue, 2004.

[6] Hanifah U, \& Andrianto, M. Experimental study on fuel consumption and energy efficiency at soymilk cooking Using a Mini Boiler and Using a Gas Stove. In 2018 4th International Conference on Science and Technology (ICST), 2018, pp.4-8.

[7] Qamaruddin, \& Sikki, M. I, Analisis kebutuhan bahan bakar terhadap perubahan tekanan uap. Jurnal Ilmiah Teknik Mesin, 4(2), 2016, 67-74.
[8] Sugiono, Metode Penelitian Kuantitatif Kualitatif dan R \& D. Bandung: Alfabeta, 2009

[9] Rusnoto, Perencanaan Ketel Uap Tekanan 6 Atm dengan Bahan Bakar Kayu untuk Industri Sederhana. Oseatek, Edisi 4, 2008, Hal 32-35.

[10] Singer F.L dan A. Pytel. Kekuatan Bahan (Teori KokohStrenght of Materials). Jakarta, 1985, Erlangga.

[11] ASME, Boiler and pressure vessel code Section II Materials Part a Ferrous Specifications (Beginning SA450), 2017. 